\title{
THE CONVERGENCE OF INTERNET AND RADIO IN TURKEY IN THE PERSPECTIVE OF DISTRIBUTION AND AUDIENCE
}

\author{
Mihalis KUYUCU \\ İstanbul Aydın University, Istanbul \\ michaelkuyucu@gmail.com
}

\begin{abstract}
The technological developments in the technology had effected media in different ways. It contributed radio, tv and print media which is called as traditional media's distribution channels to be shaped again. From this effect radio has taken its role and new media has merged with radio which this has create a difference in both technologic and economic structure. In this paper, there has been done a research on the change of radio with the emergence that has with new media, it has underlined that radio has found the possibility to improve its power with that emergence. Listening to radio via internet has been increasing from day to day and the radio audience has found a possibility of listening to radio with the new distribution that this new technologic developments has created. This new form of listening radio has changed the interaction of the audience and radio station from one to two communication and this has caused radio stations to have better feedbacks and a two way communication with its audience. This two way communication has also contributed radio and new media's meeting. Radio now can make sale of a service or product via e-commerce and can improve its economic power more than the past.
\end{abstract}

Key Words: Radio Broadcasting, Internet, e-commerce, Social Media, Media Researches

\section{YAYIN BİÇIMII VE DİNLEYICCI PERSPEKTIFINDEN TÜRKIYYE'DE INTERNET ILE RADYONUN YAKINSAMASI}

\begin{abstract}
ÖZET
İnternet medyasında yaşanan teknolojik gelişmeler geleneksel medyaya farklı biçimlerde etki etmiştir. Yeni medya geleneksel medya olarak adlandırılan radyo, televizyon ve yazılı basın gibi mecraların üretim ve dağıtım kanallarının yeniden şekillenmesine katkıda bulunmuştur. Bu değişimden radyo mecrası da payına düşeni almış ve radyo mecrası yeni medya ile bütünleşerek hem teknolojik anlamda hem de ekonomik anlamda farklılaşmıştır. Bu çalışmada radyo mecrasının yeni medya ile olan etkileşimi sonucunda geçirdiği değişim üzerine bir araştırma yapılmış ve radyo mecrasının internet aracılığı ile gücünü daha da büyütme fırsatı yakaladığının altı çizilmiştir. İnternet aracılığı ile radyo dinleme alışkanlığı her geçen gün artmakta ve radyo dinleyicisi radyo mecrasını internet ve yeni iletişim teknolojilerinin yarattığ 1 yeni biçimlerle bütünleşerek radyo dinlemeye başlamıştır. Yeni medya ile gücünü birleştiren radyo mecrası küreselleşme imkânı bulmuş ve yayınlarını belirli bir coğrafi alandan tüm dünyaya sunabilme şansını yakalamıştır. İnternet aracılığı ile dinlenen radyo programlarında iletişimin yönü de tek yönlü iletişimden çift yönlü iletişime doğru kaymış ve radyo mecrasının tüketicisi ile anlık iletişime geçmesi ve geri bildirimler almasına katkıda bulunmuştur. $\mathrm{Bu}$ çift taraflı iletişim radyo ile yeni medyanın e-ticarette buluşmasına katkıda bulunmuştur. Radyo mecrası artık e-ticaret sayesinde yayınında duyurduğu bir ürün veya hizmeti anında satışa dönüştürebilmekte ve ekonomik gücüne güç katabilmektedir.
\end{abstract}

Anahtar Kelimeler: Radyo Yayıncılı̆̆g, İnternet, E-Ticaret, Sosyal Medya, Medya Araştırmaları 


\section{COMMUNICATION TECHNOLOGIES AND RADIO}

The English verb "radiate" is derived from Romanesque word "radius" which is "yarı çap" in Turkish language. The word radio which is the short version of "radiate" verb is a concept used by physicists who studied mostly on electricity - for expressing wireless transmission. In time, the word "radio" which was used distinctly for wireless communication, transformed into Turkish as its pronunciation "radyo" like a lot of other terms. Technically, radio means transmission of frequencies via modulations of electromagnetic waves. (Graf, 1974:467)

According to Erdoğan and Alemdar radio is "technological extension of human ear which provides time and ground control through air and enables audibility of sound waves from space, beyond ear's hearing capacity" and consists of "integrated structure formed by a lot of functionally connected means enabling people to produce, publish and listen to the certain product". (Erdoğan \&Alemdar, 2005:17-22)

This integrated structure made contribution to progress of radio broadcasting which extended over time by means of improvements of electrical and electronics technologies. Equipments involved in publishing place called studio, system constituted by those equipments, transmitters, satellites and receivers to which these systems are connected contributed to this integrated structure and formed historical progress of radio broadcasting. In recent years, internet technologies - also called as fourth media - have joined to this structure and have radio medium experience important developments in its historical progress.

Radio is the oldest electronic communication device. Hundred years of history does not wear it out, instead, makes it more interesting. While stayed in background after the launch of televisions, it always accompanied people by expanding its service areas in the early years of 2000s. According to the opinion research "Radio Listening Trends" done by Radio and Television Supreme Council Corporation, radio broadcasting may be listened via home theater systems, classical radios, mobile/cell phones, Mp3/Mp4 players, satellite and internet. (Küçükerdoğan, 2012:62). A research company called Ipsos KMG which has been making surveys of media researches and studying on radio listening habits for radio society in Turkey since 2003, determined that radio can be listened via internet and receivers in cars, cell phones, satellite, $\mathrm{mp} 3$ players / iPods besides traditional tuners.

By 1850s telegram, between 1850-1880 telephones, by 1900's electromagnetic waves transmittal, between 1920-30 radios, between 1950-1960 televisions technologies have developed, finally new media technologies were started to be used by 1970. (Balle and Eymey,1995:18) New Media concept has expanded and reached different dimensions by means of internet and computer technology gained speed in 1990s. (Dilmen,2007:14).

New media or information technologies; is referred as technologies providing video text, internet, cable television, computer and other digital communication services by means of computer support of traditional mass communication mediums like television and radio. (Geray,1997:2-40 Aktaran Çiğdem Aytekin,2012: 104) 


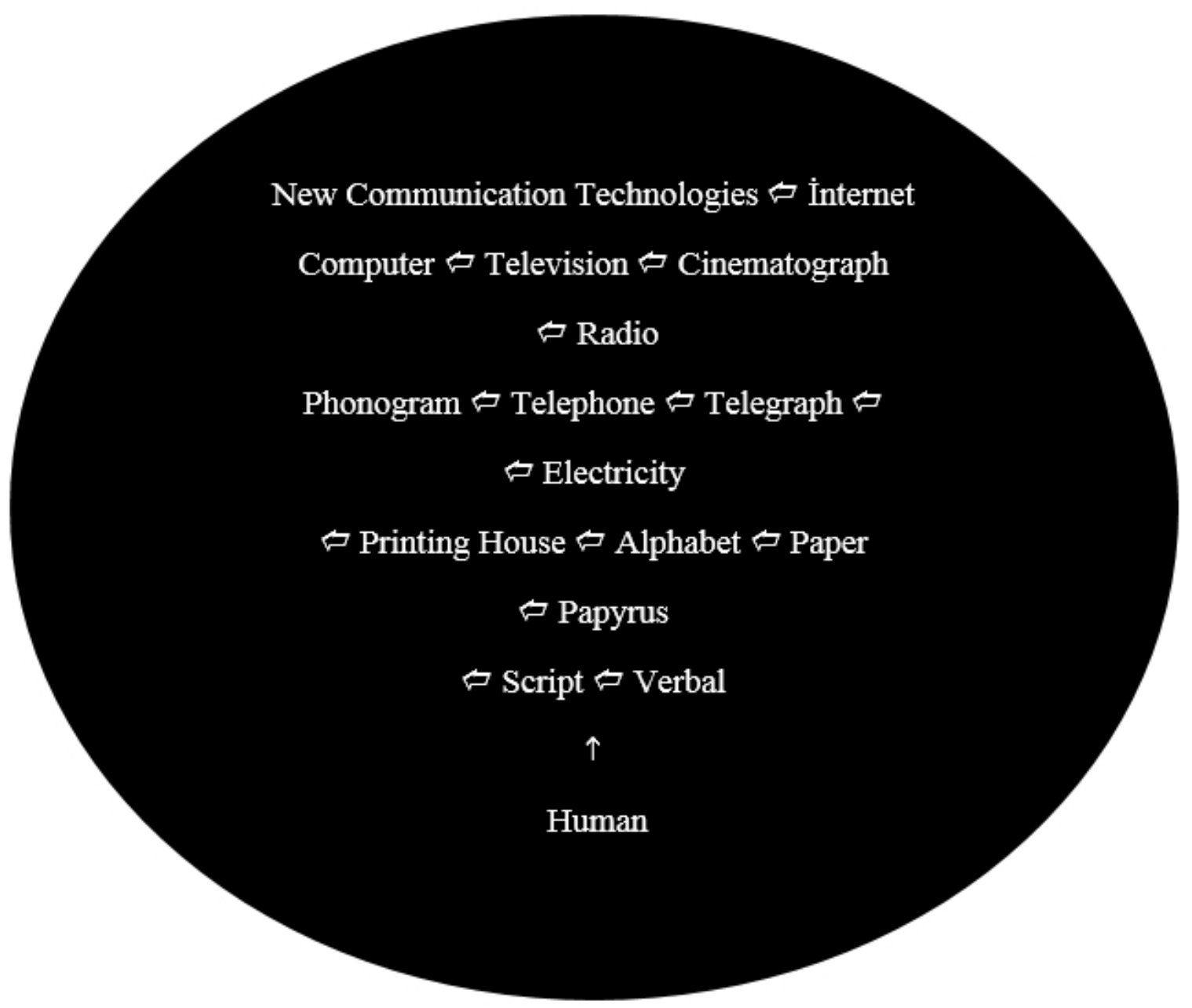

Figure 1. Developmental Communication Medium Spiral (Yengin,2010:41)

Improvements in communication technologies affected all mediums and changed broadcasting types of publications. Initial communication of primitive man starting with speech continued with scripts and come until today. During this progress, each new-born communication type also affected its predecessor together with improvement process. In time, this interaction led new types to include the previous ones and finally resulted to integration (Figure 1). Breakthroughs of internet medium also enabled radio to reach wider audience, expanded its geography and provided opportunities towards a new economic structure.

\section{THE MEETING OF RADIO AND INTERNET}

Along with improvements of internet medium, radio medium broadcasting with traditional methods continued its publications by using internet and in parallel with "globalization" phenomenon it provided publications through internet as a global product. First radio channel broadcasting via internet was a radio channel in USA called WXYC (89.3FmChapelHill). That radio channel declared in 7 November 1994 that it broadcasted via internet. In European continent, United Kingdom based Virgin Radio was the first radio channel broadcasted via internet. Virgin Radio started to broadcast its publications via internet all over the world in March of 1996. In 2004, 19 millions of people were listening radio via internet in USA (8\% of population) (Berkley, 2007:6).

Technological improvements provided by internet medium offered different technological alternatives to people who would like to listen radio via internet. One of them was a device called "AsusAirRadio" launched in 2008 by Asus. Thanks to its ability to access online radio channels through cable internet besides Wi-Fi, this radio receiver may store over 10 thousand radio channels broadcasting online. (www.radyocuyuz.comAsusAirRadyo, Date Accessed: 08.02.2013). Another technological 
improvement which has contribution to online listening process was Blaupunkt's mobile CD players having embedded internet radio application launched in 2009. Thanks to world's first internet mobile radio, owners have had the opportunity to easily access thousands of radio channel integrated with $\mathrm{AM} / \mathrm{FM} / \mathrm{CD}$ standards. If desired, miRoamer and on board internet radio which were launched together by Blaupunkt also enables listener to prefer terrestrial radio stations or internet channels. CEO of miRoamer George Parthimos stated that, drivers may access thousands of radio station by clicking only one button thanks to their internet radio solution. (www.radyocuyuz.com )

In consequence of improvements in technology world, radio stations broadcasting online found more publishing opportunities than terrestrial traditional radio stations.

\begin{tabular}{|l|l|}
\hline Traditional Radio & Radios Broadcasting Online \\
\hline $\begin{array}{l}\text { Terrestrial Broadcast } \\
\text { Receivers }\end{array}$ & Internet Connection / PC \\
\hline Automobile Receivers & Telephone (Android and Iphone Apps) \\
\hline & Smart TV \& Digital TV Platforms \\
\cline { 2 - 2 } & MP3 / Ipod Player \\
\cline { 2 - 2 } & Car Radios \\
\cline { 2 - 2 }
\end{tabular}

Table 1. Access channels of internet radios and terrestrial broadcasting radio stations.

\section{INTERNET AND RADIO IN TURKEY}

First online radio broadcasting and initial interaction of internet and radio medium in Turkey taken place in the beginning of 2000s. TRT_SAYTEK (Digital Broadcasting Technology Center) has been established in 1999 and its website became online with www.trt.net.tr address. (http://www.trt.net.tr/Kurumsal/Tarihce.aspx Access Date: 05 February 2013). In the beginning radio channels established web sites containing corporate data; afterwards they have started to transmit their broadcasts via those websites. Radio stations both in Turkey and in the World started online broadcasting by transferring their $24 / 7$ publications directly into internet medium. As soon as the internet medium became popular, domain names of radio stations gained great importance. Some radio stations fell behind the schedule of domain registration due to their late engagements in internet medium or lack of adequate importance given to that subject. Examples of it may be showed as radio stations like Joytürk and Slowtürk. Said radio stations could not register and use their domain names, therefore came up with a solution of using domain names with ".tr" prolongation. Amongst radio stations using domain names with ".tr" prolongations there were radio stations broadcasting with names in different language. Radio stations having names in different language like "PowerFm" or "Best Fm", could not use ".com" and ".net" prolongations because those names were already used in foreign countries.

Radio stations have directly shared their terrestrial broadcasts with their audience via internet. In the first internet broadcast launched by Real Audio, service rendered by the company named Shoutcast which had its headquarters in Germany afterwards have been used. While broadcasting via internet became popular, radio stations established their own servers and broadcasted with their own infrastructures. Online broadcasts of radio stations in Turkey have been executed through servers having 1000 to 5000 user capacity. Those broadcasts which could be accessed by 5000 listeners at once became an alternative of terrestrial radio broadcasts.

According to "Radio Listening Trends" opinion research done by RTUK (Radio and Television High Council), explicit increase in online listening rates has been observed. 


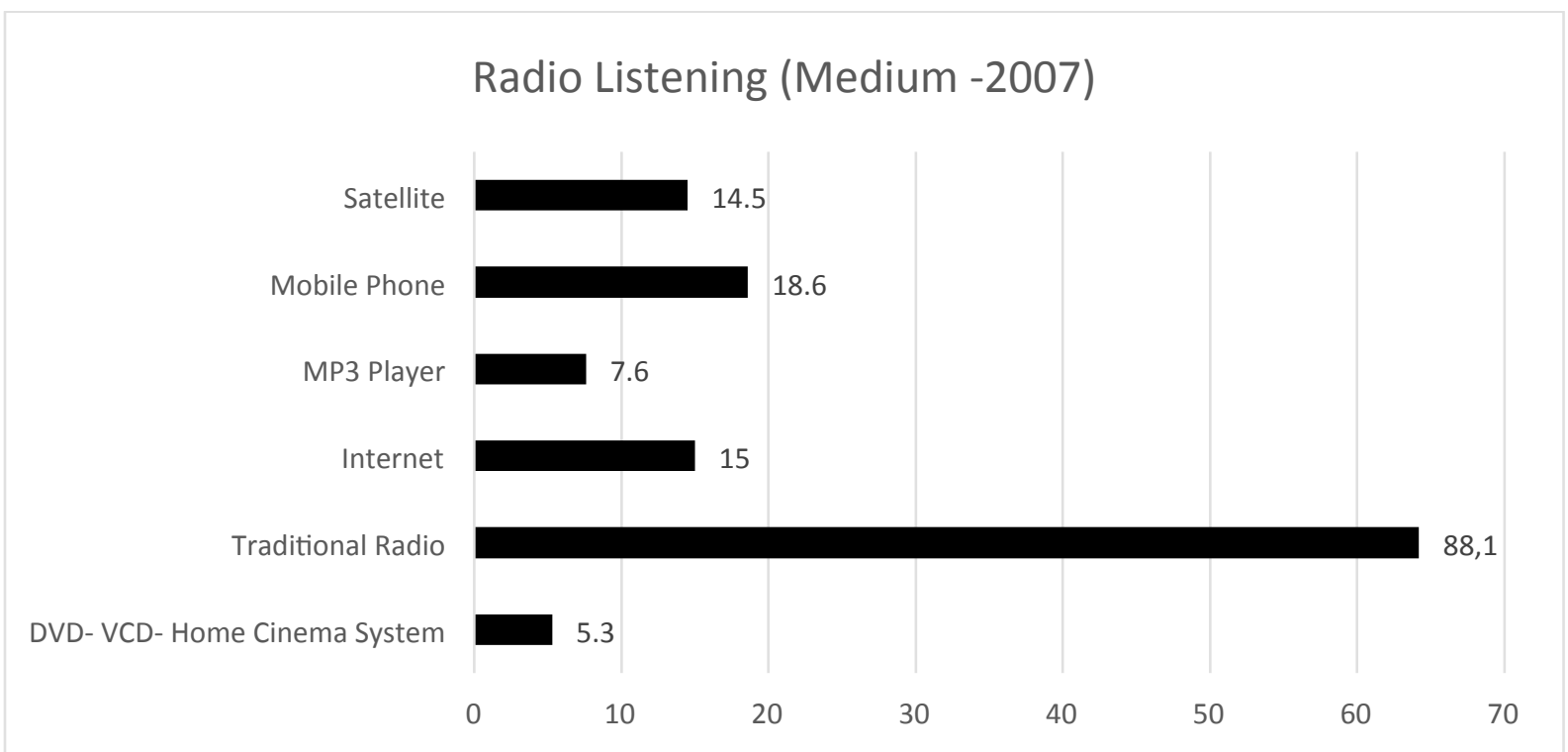

Table 2. Radio Listening Types According to "Radio Listening Trends" Research Conducted by RTÜK in 2009. (The sum exceeds 100\% because of multiple answers.) (Source: RTÜK)

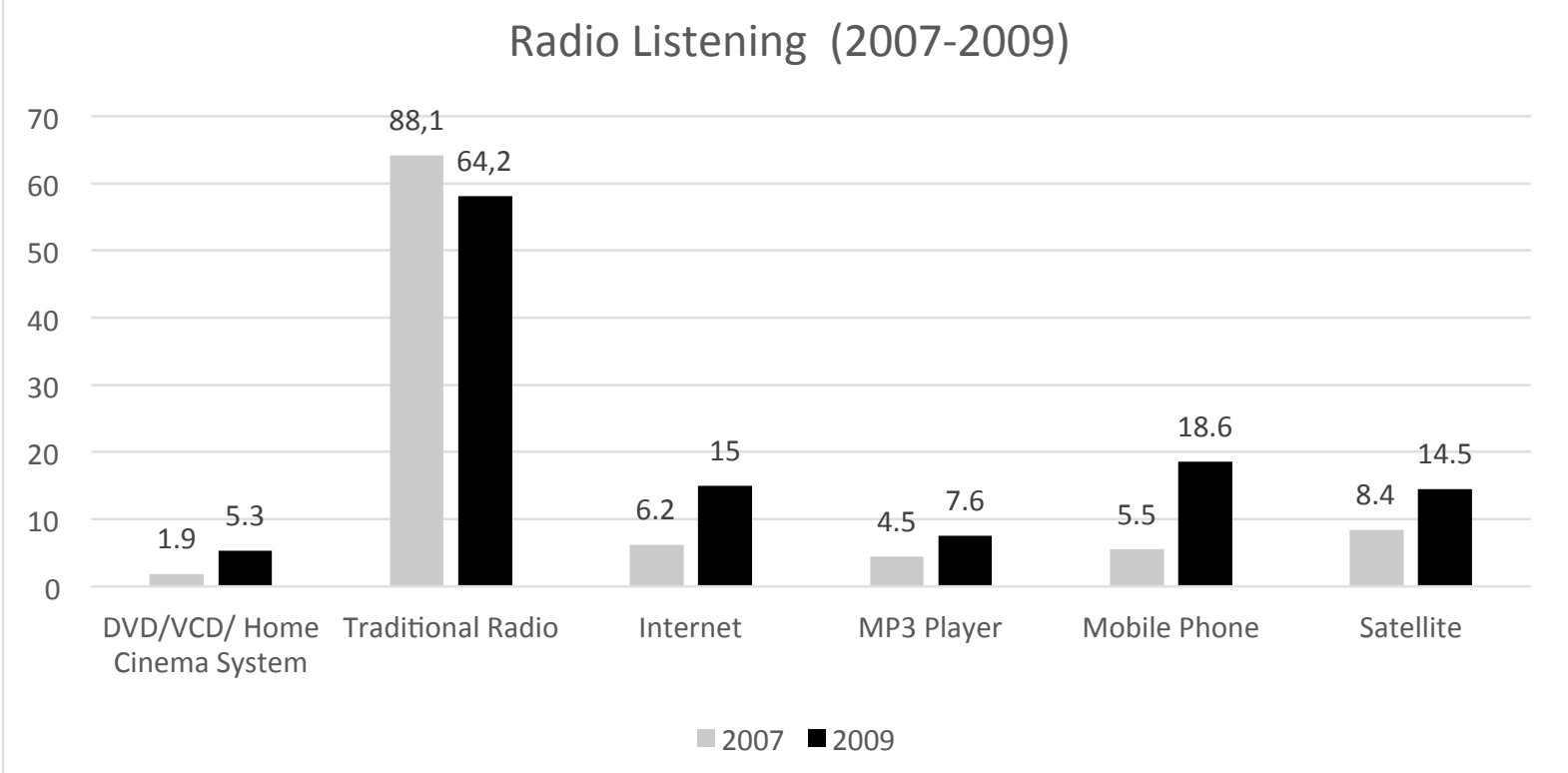

Table 3. Listening Types of Radio Medium (2007-2009) (Source: RTÜK) (The sum exceeds 100\% because of multiple answers.)

When the first "Radio Listening Habits" opinion research done by RTUK in 2007 compared with data of 2009 , it has been observed that population who listen radio with "traditional radio receiver" decreased by $23.9 \%$ while listening radio via other means like "mobile/cell phones" , "internet" and "satellites" showed increase by $13.1 \%, 8.8 \%$ and $6.1 \%$ respectively. This data was the solid proof that radio audience listen the radio via technological mediums like internet and mobile phones etc. by abandoning the habit of listening to it from traditional mediums.

Considering geographical distribution of audience who listen radio via internet, we observe that in Marmara region there is more audience listening the radio via internet.

\begin{tabular}{l|c} 
Marmara & 20,8 \\
\hline Aegean & 10,2 \\
\hline Mediterranean & 6,4 \\
\hline Central Anatolia & 13 \\
\hline Black Sea & 12,1 \\
\hline
\end{tabular}


The Turkish Online Journal of Design, Art and Communication - TOJDAC July 2014 Volume 4 Issue 3

\begin{tabular}{l|c} 
East Anatolia & 9,9 \\
\hline $\begin{array}{l}\text { Southeastern } \\
\text { Anatolia }\end{array}$ & 13,4 \\
\hline \hline
\end{tabular}

Table 4. Geographical Distribution of Online Radio Listeners (Source: RTÜK 2010) (The sum exceeds $100 \%$ because of multiple answers.)

According to "Radio Listening Trends Research - 2" demographical structure of online radio listeners are shown in Table 5.

\begin{tabular}{|l|c|}
\hline \multicolumn{2}{|l|}{ GENDER } \\
\hline Female & 15,3 \\
\hline Male & 14,6 \\
\hline AGE GROUPS \\
\hline 15-20 years old & 23,1 \\
\hline 21-25 years old & 28,4 \\
\hline 26-30 years old & 25 \\
\hline 31-35 years old & 14,7 \\
\hline 36-40 years old & 13,1 \\
\hline 41-50 years old & 9,2 \\
\hline 51-60 years old & 3,8 \\
\hline 61 years old or older & 0,7 \\
\hline MARITAL STATUS \\
\hline Married \\
\hline Single & 9,5 \\
\hline
\end{tabular}

Table 5. Demographical Structure of Online Radio Listeners (Source: RTÜK-2010) (The sum exceeds $100 \%$ because of multiple answers.)

Online listening rates of radios have been showing obvious increase by means of rapidly developing technological improvements. As a result of the analysis we conducted by compiling research data of research "radio listening habits" done by Ipsos KMG since 2003, we concluded that online radio listening habits in Turkey increased by $613 \%$ from the years 2004 to 2012 . While online radio listening rate was $2.36 \%$ in 2004, it increased up to $16.83 \%$ in 2011 .

\begin{tabular}{|c|c|}
\hline Year & Online Radio Listening Rates (\%) \\
\hline 2004 & 2.36 \\
\hline 2005 & 3.49 \\
\hline 2006 & 4.60 \\
\hline 2007 & 7.40 \\
\hline 2008 & 9.82 \\
\hline 2009 & 11.57 \\
\hline 2010 & 14.63 \\
\hline 2011 & 16.83 \\
\hline
\end{tabular}

Table 6. Online Radio Listening Rate (Compiled by Ipsos KMG Research data)

Rapid increase in online radio listening rates became the most apparent proof of interaction between the radio medium and internet. While online radio listeners listened to radio mostly at their works in 2004, they started to listen at home by 2011. 
Analysis about listening types of online radio listeners between 2004 and 2011 have been shown in Table 7 . While $41 \%$ of online radio listeners were listening radio at home, $52 \%$ of them listened to radio at their works.

\begin{tabular}{|c|c|c|c|}
\hline Year & Home & Work & Other \\
\hline 2004 & 41 & 52 & 16 \\
\hline 2005 & 49 & 48 & 12 \\
\hline 2006 & 59 & 39 & 10 \\
\hline 2007 & 69 & 29 & 8 \\
\hline 2008 & 80 & 23 & 5 \\
\hline 2009 & 81 & 24 & 7 \\
\hline 2010 & 84 & 22 & 5 \\
\hline 2011 & 84 & 23 & 5 \\
\hline
\end{tabular}

Table 7. Listening Type / Place of Online Radio Listeners

When we analyze online radio listening habits of 2012 in a monthly basis, there are seasonal changes in online radio listening rates as shown in Table 8. While online radio listening increases in spring and summer season, it shows a decrease in autumn and winter seasons. We may interpret this trend as the result of radio listeners being mobile or on vacation who prefer online radio listening instead of listening to terrestrial broadcast receivers.

\begin{tabular}{|l|c|}
\hline Month & Online Radio Listening Rate (\%) \\
\hline January & 7.38 \\
\hline February & 7.45 \\
\hline March & 7.96 \\
\hline April & 8.37 \\
\hline May & 8.44 \\
\hline June & 8.16 \\
\hline July & 8.18 \\
\hline August & 9.52 \\
\hline September & 8.88 \\
\hline October & 8.52 \\
\hline November & 7.31 \\
\hline December & 7.06 \\
\hline
\end{tabular}

Table 8. Online Radio Listening Rates of 2012 in Monthly Basis (Compiled by Ipsos KMG Research Data)

*Answers of respondents, who have indicated that they listen to the radio not only from one source but from more than one source at the same time, have also been included in the data in question.

\begin{tabular}{|l|c|c|c|}
\hline Month & $\begin{array}{c}\text { Home } \\
(\mathbf{\%})\end{array}$ & $\begin{array}{c}\text { Workplace } \\
(\mathbf{\%})\end{array}$ & $\begin{array}{c}\text { Other } \\
(\mathbf{\% )}\end{array}$ \\
\hline January & 82 & 23 & 5 \\
\hline February & 82 & 22 & 4 \\
\hline March & 83 & 21 & 3 \\
\hline April & 82 & 23 & 4 \\
\hline May & 81 & 24 & 4 \\
\hline June & 78 & 27 & 4 \\
\hline
\end{tabular}


The Turkish Online Journal of Design, Art and Communication - TOJDAC July 2014 Volume 4 Issue 3

\begin{tabular}{|l|l|l|l|} 
July & 79 & 25 & 3 \\
\hline August & 82 & 21 & 2 \\
\hline September & 84 & 21 & 2 \\
\hline October & 82 & 22 & 3 \\
\hline November & 82 & 23 & 5 \\
\hline December & 79 & 25 & 5 \\
\hline
\end{tabular}

Table 9. Online Radio Listening Type / Place of Listeners in 2012

When we consider monthly listening types of online radio listeners in 2012, we observe that in-house listeners are four times more than at-work listeners.

\begin{tabular}{|l|l|l|}
\hline Rank & Radio & Reach (\%) \\
\hline 1 & KRAL FM & $1.25 \%$ \\
\hline 2 & POWER TURK & $1.03 \%$ \\
\hline 3 & SLOW TURK & $0.78 \%$ \\
\hline 4 & SUPER FM & $0.55 \%$ \\
\hline 5 & NUMBER ONE FM & $0.42 \%$ \\
\hline 6 & RADYO FENOMEN - ISTANBUL & $0.41 \%$ \\
\hline 7 & POWER FM & $0.39 \%$ \\
\hline 8 & JOY TURK & $0.38 \%$ \\
\hline 9 & ALEM FM & $0.32 \%$ \\
\hline 10 & SHOW RADYO & $0.30 \%$ \\
\hline 11 & TRT FM & $0.28 \%$ \\
\hline 12 & METRO FM & $0.26 \%$ \\
\hline 13 & BEST FM & $0.26 \%$ \\
\hline 14 & KRAL POP & $0.22 \%$ \\
\hline 15 & RADYO D & $0.18 \%$ \\
\hline 16 & JOY FM - ISTANBUL & $0.17 \%$ \\
\hline 17 & RADYO MYDONOSE - ISTANBUL & $0.14 \%$ \\
\hline 18 & ISTANBUL FM - ISTANBUL & $0.14 \%$ \\
\hline 19 & RADYO 7 & $0.13 \%$ \\
\hline 20 & RADYO SEYMEN & $0.13 \%$ \\
\hline
\end{tabular}

*Answers of respondents, who have indicated that they listen to the radio not only from one source but from more than one source at the same time, have also been included in the data in question.

Table 10. Top 20 Radio Stations according to Online Radio Listening Habits (Compiled by Ipsos KMG 2012 December Data)

\begin{tabular}{|c|c|c|c|c|}
\hline & & Reach (\%) & $\begin{array}{c}\text { Average } \\
\text { Listening Time } \\
\text { (sec.) }\end{array}$ & $\begin{array}{c}\text { Total Listening Time } \\
\qquad(1,000 \mathrm{hr})\end{array}$ \\
\hline Rank: & Radio: & & & \\
\hline 1 & KRAL FM & $1,46 \%$ & 278 & 1.975 \\
\hline 2 & POWER TURK & $1,22 \%$ & 295 & 1.758 \\
\hline 3 & SLOW TURK & $0,80 \%$ & 278 & 1.079 \\
\hline 4 & SUPER FM & $0,67 \%$ & 219 & 718 \\
\hline 5 & JOY TURK & $0,56 \%$ & 295 & 805 \\
\hline 6 & NUMBER ONE FM & $0,52 \%$ & 181 & 460 \\
\hline 7 & RADYO & $0,51 \%$ & 263 & 657 \\
\hline
\end{tabular}




\begin{tabular}{|c|l|r|r|r|} 
& FENOMEN & & & 472 \\
\hline 8 & SHOW RADYO & $0,43 \%$ & 228 & 720 \\
\hline 9 & POWER FM & $0,40 \%$ & 366 & 588 \\
\hline 10 & ALEM FM & $0,37 \%$ & 330 & 422 \\
\hline 11 & METRO FM & $0,34 \%$ & 256 & 385 \\
\hline 12 & TRT FM & $0,32 \%$ & 248 & 464 \\
\hline 13 & BEST FM & $0,30 \%$ & 315 & 189 \\
\hline 14 & RADYO D & $0,29 \%$ & 134 & 116 \\
\hline 15 & RADYO 7 & $0,26 \%$ & 94 & 425 \\
\hline 16 & KRAL POP & $0,25 \%$ & 351 & 115 \\
\hline 17 & $\begin{array}{l}\text { JOY FM - } \\
\text { ISTANBUL }\end{array}$ & $0,19 \%$ & 345 & 116 \\
\hline 18 & RADYO SEYMEN & $0,18 \%$ & 134 & 112 \\
\hline 19 & RADYO & 138 & \multirow{2}{*}{ TURKUVAZ } \\
\hline \multirow{2}{*}{20} & $\begin{array}{l}\text { RADYO } \\
\text { MYDONOSE - } \\
\text { ISTANBUL }\end{array}$ & $0,17 \%$ & 161 & \\
\hline
\end{tabular}

Table 11. Top 20 Radio Stations of January 2013 According to Online Radio Listening Habits (Compiled by Ipsos KMG 2013 January Data)

According to research about determination of radio listening habits done by Ipsos KMG Research Company, it is shown that Kral FM is the number one radio station amongst the online listened radios. While $1.46 \%$ of online radio listeners listen to Kral Fm, $1.22 \%$ of them listen to Powertürk and $0.8 \%$ of them listen to Slowtürk. According to data published by Ipsos KMG in February of 2013, those three radio stations are the most online-listened radio stations of Turkey.

\begin{tabular}{|c|l|c|c|c|}
\cline { 3 - 5 } \multicolumn{2}{l|}{} & 2013-January & 2013-Febr. & 2013-March \\
\hline Rank & Radio & Reach & Reach & Reach \\
\hline 1 & KRAL FM & $2.85 \%$ & $2.78 \%$ & $2.98 \%$ \\
\hline 2 & POWER TURK & $2.43 \%$ & $2.35 \%$ & $2.36 \%$ \\
\hline 3 & SLOW TURK & $1.55 \%$ & $1.70 \%$ & $1.87 \%$ \\
\hline 4 & SUPER FM & $1.32 \%$ & $1.37 \%$ & $1.29 \%$ \\
\hline 5 & NUMBER ONE FM & $1.01 \%$ & $1.14 \%$ & $0.98 \%$ \\
\hline
\end{tabular}

Table 12. Top Five Online-Listened Radio Stations in Turkey and Their Access Percentages

According to the analysis we conducted by compiling research data of research "radio listening habits" done by Ipsos KMG, top five online-listened radio stations in Turkey as of the first quarter of 2013 have been shown in table 12. Within this frame, Kral FM has become the top online-listened radio station in the field of Turkish Music and Number One FM was the most online-listened radio station in the field of Foreign Music.

\begin{tabular}{|c|l|c|c|l|c|}
\cline { 3 - 4 } \multicolumn{2}{l|}{} & 2013- Jan. & $\begin{array}{c}\text { 2013- } \\
\text { Febr. }\end{array}$ & 2013-Mach \\
\hline Rank & & Reach & Reach & Total & Reach \\
\hline 1 & KRAL FM & $2.47 \%$ & $2.46 \%$ & KRAL FM & $2.53 \%$ \\
\hline 2 & POWER TURK & $2.33 \%$ & $2.33 \%$ & POWER TURK & $2.51 \%$ \\
\hline 3 & SLOW TURK & $1.68 \%$ & $1.67 \%$ & SLOW TURK & $2.00 \%$ \\
\hline
\end{tabular}




\begin{tabular}{|c|l|c|c|l|c|}
4 & JOY TURK & $1.68 \%$ & $1.65 \%$ & JOY TURK & $1.57 \%$ \\
\hline 5 & $\begin{array}{l}\text { NUMBER ONE } \\
\text { FM }\end{array}$ & $1.52 \%$ & $1.56 \%$ & $\begin{array}{l}\text { RADYO } \\
\text { FENOMEN }\end{array}$ & $1.24 \%$ \\
\hline
\end{tabular}

Table 13. Top five radio stations listened online in Istanbul

\begin{tabular}{|c|c|c|c|c|c|}
\hline & & 2013 - Jan. & $\begin{array}{l}2013- \\
\text { Febr. }\end{array}$ & & 2013 - March \\
\hline Rank & & Reach & Reach & & Reach \\
\hline 1 & SLOW TURK & $2.23 \%$ & $2.10 \%$ & SLOW TURK & $2.29 \%$ \\
\hline 2 & $\begin{array}{l}\text { PARK FM - } \\
\text { ANKARA }\end{array}$ & $1.53 \%$ & $1.71 \%$ & POWER TURK & $1.59 \%$ \\
\hline 3 & POWER TURK & $1.98 \%$ & $1.61 \%$ & $\begin{array}{l}\text { PARK FM - } \\
\text { ANKARA }\end{array}$ & $1.58 \%$ \\
\hline 4 & SUPER FM & $1.65 \%$ & $1.34 \%$ & SUPER FM & $1.05 \%$ \\
\hline 5 & RADYO VIVA & $0.88 \%$ & $1.12 \%$ & $\begin{array}{l}\text { NUMBER ONE } \\
\text { FM }\end{array}$ & $0.97 \%$ \\
\hline
\end{tabular}

Table 14. Top five radio stations listened online in Ankara

When we consider distribution by provinces of top five radio stations in the first quarter of 2013, we see that different radios in Istanbul - Ankara and İzmir have different ranks with different reach rates. In this analysis which also sets an example for internet consumption habits by cultural alterations and geographical distribution of Turkey, it is shown that different provinces of Turkey have different radio listening habits.

\begin{tabular}{|c|l|c|c|c|c|}
\cline { 3 - 4 } \multicolumn{2}{l|}{} & 2013-Jan. & $\begin{array}{c}\text { 2013- } \\
\text { Febr. }\end{array}$ & $\begin{array}{c}\text { 2013 - } \\
\text { March }\end{array}$ \\
\hline Rank & & Reach & Reach & & Reach \\
\hline 1 & $\begin{array}{l}\text { POWER } \\
\text { TURK }\end{array}$ & $4.50 \%$ & $3.70 \%$ & POWER TURK & $3.40 \%$ \\
\hline 2 & $\begin{array}{l}\text { RADYO } \\
\text { FENOMEN }\end{array}$ & $3.42 \%$ & $3.34 \%$ & $\begin{array}{l}\text { RADYO } \\
\text { FENOMEN }\end{array}$ & $2.66 \%$ \\
\hline 3 & POWER FM & $1.13 \%$ & $1.79 \%$ & KRAL FM & $2.28 \%$ \\
\hline 4 & RADYO D & $1.75 \%$ & $1.67 \%$ & ALEM FM & $1.85 \%$ \\
\hline 5 & $\begin{array}{l}\text { NUMBER } \\
\text { ONE FM }\end{array}$ & $1.49 \%$ & $1.48 \%$ & RADYO D & $1.70 \%$ \\
\hline
\end{tabular}

Table 15. Top ten radio stations listened online in İzmir

Different rates of online radio listening in Turkey may be interpreted as the reflection of heterogeneous cultural structure of the country. Radio stations broadcasting the same content in three different cities, have had different access rates.

\section{SOCIAL MEDIA AND RADIO}

While Facebook has had 980 million registered users in 2012, Twitter increased those users count over 500 million. While a registered YouTube user spends daily fifteen minutes in average, three million blogs have been going online in every month and daily five million pictures are being uploaded to Instagram. (Bullas, 2013:5). Those trends have continuously been enhancing social media and been increasing its importance day by day.

While online radio broadcasts enhancing its accessibility, growth in social media has directed radio stations towards social media medium. Radio stations even engaged in a competition with each other while struggling to survive in social media. 
Nowadays, radio stations have been striving to survive in social media and been using it as a communication mean instead of taking advantages of social media economy and producing high income from it. While social media economy in United States was 2.1 billion dollars in 2010, Turkey could not make any significant progress in that area.

Along with improvement of social media, radio stations have been maintaining their activities by opening an account in popular mediums of special media like Facebook - Twitter and YouTube.

\begin{tabular}{|c|l|l|}
\hline Rank & Radio: & No of Subscribers \\
\hline 1 & İHeartRadio & $5,377,796$ \\
\hline 2 & Pandora & $4,943,245$ \\
\hline 3 & NRJ & $1,803,161$ \\
\hline 4 & Radio UOL & $1,399,173$ \\
\hline 5 & Skyrock & $1,305,145$ \\
\hline 6 & HOT FM & $1,303,145$ \\
\hline 7 & Kral Fm & $1,172,452$ \\
\hline 8 & Radio Italia solomusc aitaliana & $1,153,829$ \\
\hline 9 & Radio Disney Latinoamerica & $1,103,220$ \\
\hline 10 & Kiss Fm & $1,089,107$ \\
\hline
\end{tabular}

Table 16. Top Radio Stations of the World Having Most Subscribers on Facebook (Source: Socialbakers, 15 March 2014)

\begin{tabular}{|c|l|l|}
\hline Rank & Radio Station & Followers \\
\hline 1 & Radio Deejay (@radiodeejay) & 988,621 \\
\hline 2 & Radio105 (@Radio105) & 666,725 \\
\hline 3 & The BEAT (@982thebeat) & 502,898 \\
\hline 4 & RDS (@RDS_Offiicial) & 502,898 \\
\hline 5 & Radio Galau Fm (@RadioGalauFM) & 470,095 \\
\hline 6 & Power Fm (@power100fm) & 416,422 \\
\hline 7 & Los40 Principales (@LLos40_Spain) & 305,104 \\
\hline 8 & La Fm (@noticierodelafm) & 294,689 \\
\hline 9 & Faizai İsmail (@faizal_hotfm) & 290,511 \\
\hline 10 & RadioKissKiss (@radiokisskiss) & 266,933 \\
\hline
\end{tabular}

Table 17. Top Radio Twitter Accounts in the World Having Most Followers (Source: 15 March 2014)

Turkish radio stations realized social media networks much later than other radio stations in the world. Radio stations of Turkey started to place emphasis on social media networks especially in 2009 and tried to exist in that area mainly between 2010 and 2012. Nevertheless, the data that Turkish radio station called Power FM is the one of the top radio stations having most followers in Twitter, should not be underestimated. Similar situation has been also observed for Facebook users, Kral Fm from Turkey remained one of top ten radio stations of the world having the most subscribers in Facebook pages. Radio stations called Kral Fm has had the similar results in Facebook using statistics in Turkey which is one of the top five Facebook-using countries in the world.

According to research we conducted regarding national radio stations broadcasting in Turkey, we have been observing that radio stations are connecting social media through Facebook and Twitter. Statistics of national broadcasting radio stations on two of the most popular networks of internet world, Facebook and Twitter, have been listed below: 


\begin{tabular}{|c|l|l|r|}
\hline Rank: & Radio Name & $\begin{array}{l}\text { Reach- } \\
\text { Rating (\%) }\end{array}$ & Number of People Who Likes It \\
\hline 1 & KRAL FM & $10.50 \%$ & $1,179,135$ \\
\hline 2 & POWER TURK & $6.67 \%$ & 603,899 \\
\hline 3 & SLOW TURK & $4.10 \%$ & 39,824 \\
\hline 4 & SUPER FM & $3.81 \%$ & 133,480 \\
\hline 5 & TRT FM & $3.42 \%$ & 2,164 \\
\hline 6 & ALEM FM & $2.76 \%$ & 10,627 \\
\hline 7 & POWER FM & $2.59 \%$ & 158,345 \\
\hline 8 & BEST FM & $2.58 \%$ & 140,100 \\
\hline 9 & JOY TURK & $2.46 \%$ & 14,953 \\
\hline 10 & NUMBER ONE FM & $2.34 \%$ & 767,205 \\
\hline 11 & RADYO SEYMEN & $2.05 \%$ & 5,560 \\
\hline 12 & RADYO D & $2.04 \%$ & 18,586 \\
\hline 13 & METRO FM & $1.85 \%$ & 233,279 \\
\hline 14 & SHOW RADYO & $1.82 \%$ & 31,621 \\
\hline 15 & RADYO TURKUVAZ & $1.51 \%$ & 16,562 \\
\hline 16 & KRAL POP & $1.41 \%$ & 351,212 \\
\hline 17 & RADYO VIVA & $1.40 \%$ & 44,845 \\
\hline 18 & RADYO TATLISES & $1.35 \%$ & 3,733 \\
\hline 19 & RADYO 7 & $1.14 \%$ & 9,146 \\
\hline 20 & NTV RADYO & $0.85 \%$ & 16,051 \\
\hline 21 & KANALTURK RADYO & $0.73 \%$ & 12,378 \\
\hline 22 & PAL FM & $0.67 \%$ & 73,739 \\
\hline 23 & VIRGIN RADIO & $0.66 \%$ & 108,945 \\
\hline 24 & NUMBER ONE TURK FM & $0.59 \%$ & 13,160 \\
\hline 25 & TGRT FM & $0.57 \%$ & 5,172 \\
\hline 26 & MORAL FM & $0.53 \%$ & 6,659 \\
\hline 27 & SLOW TIME & $0.50 \%$ & 6896 \\
\hline 28 & SEMERKAND RADYO & $0.48 \%$ & 084 \\
\hline 29 & TRT RADYO 1 & $0.40 \%$ & \\
\hline $18:$ & FabOK Page LIKS & \\
\hline
\end{tabular}

Tablo 18: Facebook Page Likes and Reaches of National Broadcasting Radio Stations (Source: Compiled from Ipsos KMG, Facebook.com, 15 February 2013 dated research data)

As seen in Table 13 providing with number of individuals registered to Facebook pages of national broadcasting radio stations, there is no meaningful analogy between accesses of radio stations and individuals who are subscribed this Facebook page. Similarly, radio stations having high "like" rate in Facebook have not high access rates too.

\begin{tabular}{|c|l|r|r|}
\hline Rank: & Radio & $\begin{array}{l}\text { Reach } \\
(\%)\end{array}$ & Followers \\
\hline 1 & KRAL FM & $10.50 \%$ & 19,502 \\
\hline 2 & POWER TURK & $6.67 \%$ & 135,764 \\
\hline 3 & SLOW TURK & $4.10 \%$ & 7,139 \\
\hline 4 & SUPER FM & $3.81 \%$ & 35.688 \\
\hline 5 & TRT FM & $3.42 \%$ & \\
\hline
\end{tabular}




\begin{tabular}{|c|l|r|r|}
6 & ALEM FM & $2.76 \%$ & 2,782 \\
\hline 7 & POWER FM & $2.59 \%$ & 135,474 \\
\hline 8 & BEST FM & $2.58 \%$ & 60,556 \\
\hline 9 & JOY TURK & $2.46 \%$ & 37,422 \\
\hline 10 & NUMBER ONE FM & $2.34 \%$ & 20,472 \\
\hline 11 & RADYO SEYMEN & $2.05 \%$ & 2,406 \\
\hline 12 & RADYO D & $2.04 \%$ & 3.284 \\
\hline 13 & METRO FM & $1.85 \%$ & 123,398 \\
\hline 14 & SHOW RADYO & $1.82 \%$ & 10,998 \\
\hline 15 & RADYO TURKUVAZ & $1.51 \%$ & 3,709 \\
\hline 16 & KRAL POP & $1.41 \%$ & 66,361 \\
\hline 17 & RADYO VIVA & $1.40 \%$ & 6,360 \\
\hline 18 & RADYO TATLISES & $1.35 \%$ & 6,901 \\
\hline 19 & RADYO 7 & $1.14 \%$ & 3,429 \\
\hline 20 & NTV RADYO & $0.85 \%$ & 10,591 \\
\hline 21 & KANALTURK RADYO & $0.73 \%$ & 5,238 \\
\hline 22 & PAL FM & $0.67 \%$ & 14,804 \\
\hline 23 & VIRGIN RADIO & $0.66 \%$ & 23.423 \\
\hline 24 & NUMBER ONE TURK FM & $0.59 \%$ & 10,369 \\
\hline 25 & TGRT FM & $0.57 \%$ & 1,084 \\
\hline 26 & MORAL FM & $0.53 \%$ & 5,316 \\
\hline 27 & SLOW TIME & $0.50 \%$ & 592 \\
\hline 28 & SEMERKAND RADYO & $0.48 \%$ & 5,082 \\
\hline 29 & TRT RADYO 1 & $0.40 \%$ & 95 \\
\hline
\end{tabular}

Tablo 19. Access Rates and Twitter Followers Count of Radio Stations Broadcasting with National License

\section{INTERNET (WEB) RADIO}

Radio stations broadcasting only via internet by using internet technologies are called as internet radios. Main difference between traditional radio and internet radio is that those radios only broadcast via internet contrary to traditional radio stations which broadcast by using terrestrial receivers. The term "internet radio" was firstly used in 1993 by Carl Malamud as the name of radio called MBONE. In February of 1995, first internet radio Radio Hk broadcasting 24 hours a day was launched by Norman Hajjar. (Linux Magazine, 2006:66)

Features of Internet Radio: Main difference between traditional radio and internet radio is that internet radio has more interactive features than traditional radio. 


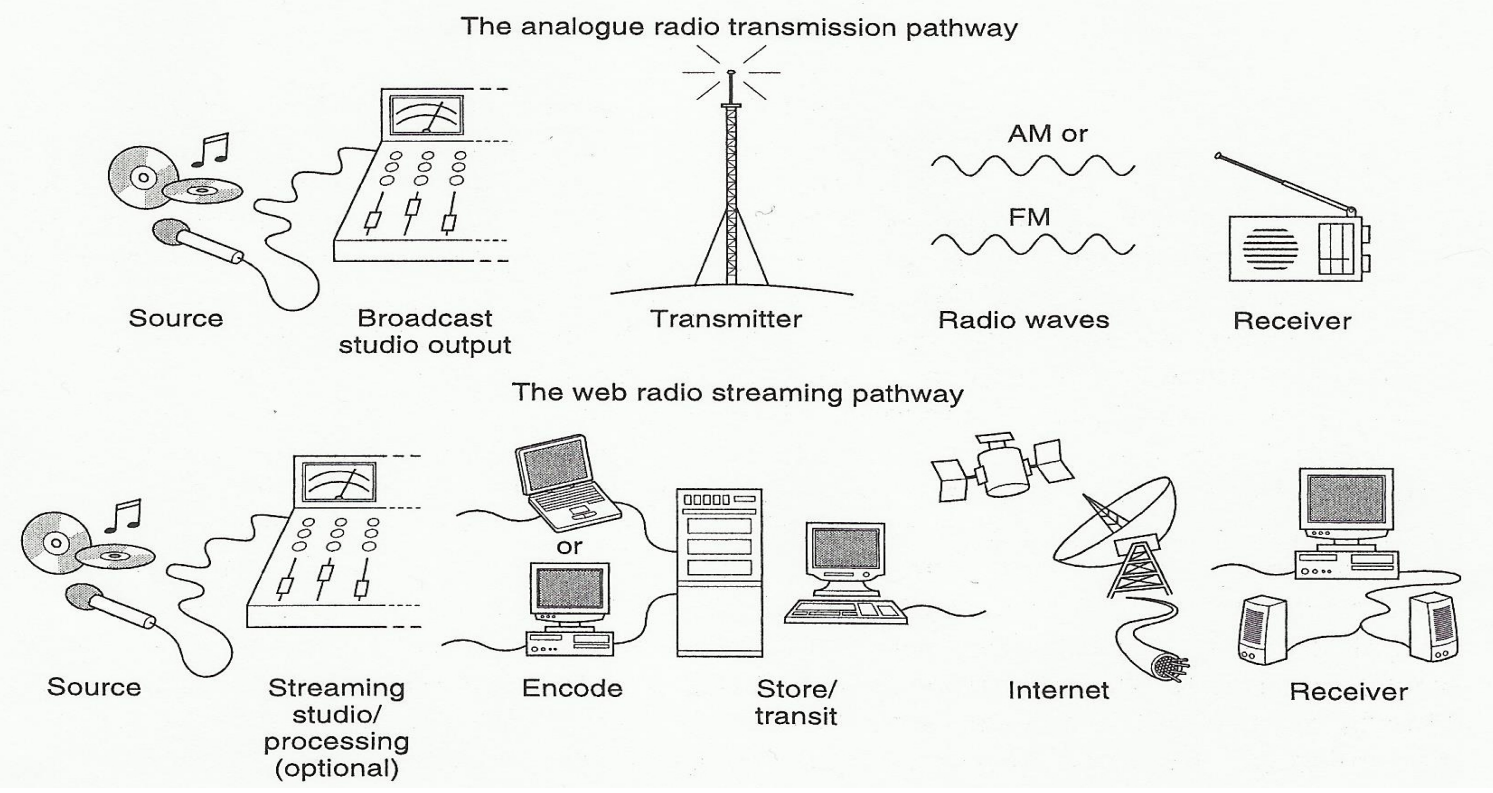

Figure 2. Difference of Terrestrial Broadcasting Radio from an Internet Radio (Priestman, 2006:9)

As seen in Figure 2, while radio broadcasting via terrestrial receivers may only communicate with its audience single-sided, radio broadcasting via internet may provide mutual communication opportunity. Radio listener may immediately interact with radio station as a result of the communication opportunities provided by internet technology and may give prompt feedback during the broadcast. Basic features of internet radio may be stated as follows:

Internet radio provides content to more narrow and niche audience. An internet radio launched for the music taste of certain target audience may broadcast only rock, classical or similar genres. Internet radio may precisely satisfy the needs of its audience by means of that feature.

Internet radio provides with its audience the opportunity of immediate feedback which that enables listener to share his/her admiration or complaints about the broadcast. Audience may evaluate the song he/she listened by voting through internet, may demand a song request by sending an e-mail or communicate with broadcaster online by simply chatting with him/her.

While number of listeners of internet radio may be determined electronically, number of listeners for traditional radios may only be established by means of periodical audience researches. Number of listener or listening trends for traditional radio stations may only be determined by researches done with journal or survey methods. For internet radios, however, those numbers may be digitally determined with $100 \%$ accuracy.

While traditional radios may broadcast only for certain geographical regions in where it broadcast with terrestrial receivers, internet radio may broadcast globally. In direct proportion to technical capability of terrestrial broadcasting radio receiver, traditional radios may only broadcast for limited geographical area, while internet radios provide the global broadcasting opportunity by means of internet medium.

Internet radio may be shown as an opportunity medium for those who would like to enter into production or music broadcasting sectors. Internet radio provides opportunity to a musician or a solo singer who would like to introduce his/her first song or radio broadcaster who would like to represent his/her broadcasting talents.

Internet radio has different promotion and sales channels in comparison with traditional radio stations because internet radio takes advantages of electronic trade. While terrestrial broadcasting radio 
stations only provides spot commercials and sponsorship opportunities for establishments willing to trade, internet radio may offer on-line sales opportunities. Internet radio provides purchasing opportunity of the album of the song on air by "clicking" only one button, and sales potential of any product by means of commercial banners located on player of radio and also creates a synergy between radio and e-shopping.

Internet radio is cheaper than traditional radios. In order to launch terrestrial broadcasting radio station, a frequency should be hired and a transmitter system should be installed in geographical region in which broadcasting is planned. This system is highly expensive. In order to broadcast via internet, a server and internet connection are enough. While frequency rents and receiver costs of an Istanbul-based radio station willing to broadcast with terrestrial receivers should require monthly 30 35 thousand dollars of investment, 300-500 Turkish Liras is adequate for launching an Istanbul-based internet radio.

\section{INTERNET (WEB) RADIO BROADCASTING IN TURKEY}

Turkey has had its share of rapidly increasing internet radios of the world and thousands of individual and commercial internet radios broadcasting via internet have been being active since 2005. First commercial internet radio of Turkey is launched by Power Media Group Companies. Independently of its terrestrial broadcasting radios called Power Fm and Powertürk; group has launched thematic radio stations broadcasting only via internet and became operating with the name Powertürk Web Radios. Group has shut down those radio broadcasts a while ago. After that initiative, for a long time period, there was no other group in Turkish Media investing in internet radios.

While media groups continuing their broadcasting activities with traditional methods did not attach much importance to internet radios, information world has considered this technology significant and invested in this medium differently. Nowadays, internet radios of digital music platforms like Digitürk TV Platform, TTNET Music and Turkcell Music have been carrying out their activities for different music tastes.

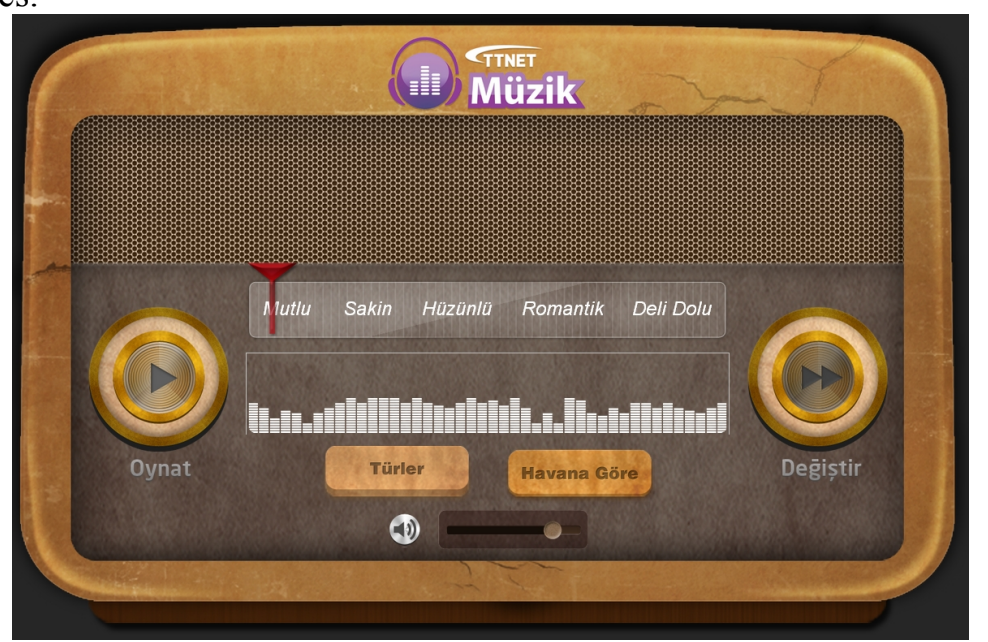

Figure 3. TTNET Music Internet Radios

Digital music platform called Turkcell Music made the biggest investment in internet radio and launched exactly 26 internet radios broadcasting in special genres like arabesque, popular party songs, jazz, R\&B, Hip-Hop and instrumental.

Latest investment made in that subject was internet radio platform called "Karnaval" which has been launched in 2011 by Spectrum Medya Labs, the digital section of Spectrum Medya incorporating terrestrial broadcasting radios like Süper Fm- Metro Fm - Joy Fm - Joytürk - Radyo Mydonose. Platform called Karnaval.com which has achieved a phenomenal success by ranking amongst the finalists of "Best Digital Strategy" category of RAIN Internet Radio Awards Competition together with world's most successful digital radio platforms like Spotify, Clear Channel, HeartRadio and ESPN, has also used the expression "a substantial radio experience which will provide music lovers the opportunity to discover new and unknown artists in addition to high quality radio listening 
experience" for defining itself (Oydar.com). Besides traditional terrestrial broadcasting radio stations like Süper Fm, Metro Fm, JoyFm, JoyTürk, Radyo Mydonose, there are some radios broadcasting only via internet like JoyTürk Akustik, Retro Türk and Zeplin in the internet radio platform called Karnaval. Latest organization investing in internet radio was legal digital music platform Fizy and it launched internet radio stations considering different musical cultures like "metal's power", "jazz pianists" and "nostalgia". The organization defines most important feature differing 2013-founded Fizy radio from the others as "guessing similar songs or similar artists by originating the artists and/or songs picked by listener and providing a tailor-made radio experience" (Source: Haberler.com) and expresses that it offers a music experience parallel to tastes of listeners with an unique experience that never existed in a traditional radio station.

\section{CONCLUSION}

Emerging new communication technologies and improving internet medium lead new media environments to rapidly involve into our lives. This new environment defined as new media made some revolutionizing changes in traditional media. Radio medium has had its share from this change created by new media and it had to renew itself in every fields.

Radio stations of the world broadcasting traditionally, one by one started to convey their broadcasts to audience via internet and tried to reach global world by transferring their broadcasts into regions where receiver signals cannot reach. While radio stations in the world introducing their broadcasts to global consumers via internet, they have also had the opportunity to change their content parallel and global broadcasting term has experienced an evolution. In the beginning, radio stations started to online-broadcast the same content that they have broadcasted through terrestrial frequencies and afterwards they have diversified their publications by launching tailor-made internet radios addressing to private tastes.

Online radio listening rate of Turkey has increased by $613 \%$ from 2004 to 2012 . Conducted listener survey researches proven that the radio medium has been listened via internet more and more every day. Listeners have been continuously abandoning the traditional radios and been preferring internet radio instead.

Social media which has been formed by improvement of new communication technologies and especially discovery of web 2.0 has had influence on radio medium. Radio stations carried out their activities in those mediums by applying popular social media channels. While global radio stations being engaged in profitable commercial activities through social media, Turkish radio stations have only strived to survive and tried to increase their brand recognition. Radio stations in Turkey have involved in social media mainly for establishing mutual communication with their listeners and increasing their brand recognition. When we examine followers count of radio stations on most famous social media networks Facebook and Twitter, we observe that there is a meaningful correlation between on air ratings of radio stations and numbers of followers on social media Networks. However, according to radio listening habits research of Ipsos KMG, every radio station having high listening rates does not have similar success in social media.

First online-only radio station of the world has been launched in 1993. Especially in 2000s, radio stations have established internet radios only broadcasting via internet and diversified their broadcast content. Media groups of Turkey moved slower in internet radio subject in comparison with radio stations of the world and did not make much investment in that field. Internet radios in Turkey were generally preferred by individual users.

Nowadays, media group making the biggest investment in internet radio is Spectrum media group companies. Besides that group establishing a new communication platform for internet radio with the platform called Karnaval, some internet platforms established cell phone networks are still active.

Contributions of new media to internet medium are not limited with globalization of accesses and diversification of broadcasting content. New media provides new income opportunities to radio stations thanks to those new communication methods. While radio stations broadcasting in traditional 
methods have limited income sources like spot commercials and sponsorships, new media provides with new opportunities about that subject. Thanks to new media, internet broadcasting radio stations met e-trade. Through e-trade a radio station may sell a product, song or album during the broadcast by publishing advertisements of that product. This common ground in which internet and radio broadcasting meet, leads a synergy between e-trade and radio medium and provides new income source for radio stations.

We could not easily say that radio stations of Turkey are taking advantages of that new media. Radio stations still believe that reaching the audience in traditional way with terrestrial broadcast would be easier and they have been carrying out their business only for existing in internet media. Although social media and economical volume of e-trade have increased, radio stations provide income usually from traditional advertising methods like spot commercials and sponsorships. Stations which could not understand the importance of sales via online radio broadcasting, have invested web sites and contentful internet-based radio platforms, so they could not take economical advantages of new media which is called as future technology. This case threatens the future of radio medium and inhibits the improvement of it because of radio broadcasting in traditional forms and methods. Within this scope, radio medium should immediately create a mutual synergy with new media.

\section{REFERENCES}

Ataman,Özlem (2009)."Sayısal Çağda Radyo Yayıncıllğı,, Selçuk Üniversitesi İletişim Dergisi :215217

BalleFrancis,EymayGerard (1995). Yeni Medyalar, Çev.Mehmet Selami Şakiroğlu, İstanbul: İletişim Yayınları.

Berkley,Holly (2007). Marketing InThe New Media, Kanada: Self CounselPress

Cavalier, Jean (2004). Dünden Bugüne Medya ve İletişim Teknolojileri (Çev.MeteÇamdereli), İstanbul : Salyangoz Yayınları

Erdem, Hasan (2011). Yeni Medya Hizmetleri ve Düzenlemeleri, RTÜK Uzmanlık Tezi, Ankara Erdoğan \& Alemdar (2005)."Öteki Kuram: Kitle İletişim Araştırmalarının Tarihsel ve Eleştirisel bir Değerlendirilmesi, Ankara: Erk Yayınları.

Geray, Haluk (1997). İletişim Teknolojilerinde Gelişmeler ve Yeni Politikalar,Bağımsız İletişim Ağı Yerel Medya Semineri Raporu

Graf,Rudolf (1974). Modern Dictionary of Electroics, Fousham-Sams

http://www.karnaval.com/about.php (08.02.2013)

http://www.oydar.com/haber/Karnaval_Android_Uygulamasi_Geliyor/1421

http://www.oydar.com/haber/Karnaval_Yeni_Radyolari_İle_Zirvede/1402 (01.10.2012)

$\mathrm{http}: / / \mathrm{www}$. radyocuyuz.com/asus-air-radio-haber.html (20.07.2008)

http://www.radyocuyuz.com/haber.asp?hb=3514haberdetay-fizynin-yeni-nesil-radyosu-yayindagundem.hmtl (29.01.2013)

http://www.radyocuyuz.com/haberdetay-internet-radyosu-simdi-de-otomobillerde.html (04.02.2013

Küçükerdoğan, Bülent (2012). Yeni Medya ve Radyoculuğun Geleceği: DigitalRadioMondaile

(DRM),Yeni Medya Ve..Editör: Deniz Yengin, İstanbul : Anahtar Kitaplar Yayınevi.

İpsos KMG Radyo Dinleme Alışkanlıklar Araştırma Verileri

Mewton,Conrad (2001) . Music \&The Internet Revolution, İngiltere : BiddlesLtd

Prestman,Chris (2002). Web Radio , ABD: FocalPress

Sylvie,G\&Wicks J (2008). Media Managemant, İngiltere : Taylor\& Francis Group

Yengin, Deniz (2010). Dijital Oyunlarda Şiddet Olgusu: Yeni Şiddet, Marmara Üniversitesi, Sosyal

Bilimler Enstitüsü, Bilişim Ana Bilim Dalı, Yayımlanmamış Doktora Tezi. İstanbul. 